\title{
EFFECT OF WEANING AS A STRESS FACTOR ON THE BLOOD ACUTE PHASE PROTEIN LEVEL IN NEWLY WEANED BUFFALOE CALVES
}

EL-SANGARY, F.H.; NOUR, E.M.; AMAL I.A. EL-SHORBAGY; EL-HADY, K.M.* and AZZA G.M. AYOUB

Animal Health Research Institute, Dokki, Zagazig Branch

*Animal Medicine Department, Faculty of Vet. Med., Zagazig University.

Email: n_king2013@yahoo.com

\section{ABSTRACT}

Received at: 17/6/2014

Weaning is one of the most widely recognized stressors in animal production. This study aimed to determine the effect of weaning as a stressor on some acute phase proteins (Haptoglobin, Fibrinogen and ceruloplasmin) response in newly

Accepted: 5/7/2014 weaned buffaloe calves. Ten newly weaned buffaloe calves of two moths of age, were used in this study. The animals belonged to a private farm in Sharkia Governorate. Blood samples were collected before weaning and $3 \& 5$ days postweaning for haematological examination and determination of the levels of plasma ceruloplasmin, fibrinogen \& cortisol and serum total proteins, albumin and haptoglobin. The obtained results revealed an alteration in the neutrophill : lymphocyte ratio, significant increase in $\mathrm{Hp}, \mathrm{Fb}, \mathrm{CRP}$ and cortisol levels, in postweaning blood samples. Moreover a decrease in serum total protein \& albumin, postweaning, was observed. From this study, it can be concluded that, stressors associated with weaning affect the acute phase- protein response in newly weaned calves.

Key words: Weaning, Stress factor, Acute phase protein.

\section{INTRODUCTION}

Animals undergo a variety of stressors within normal production process. In general, these stressors grouped into two broad categories: 1- Psychological stress, as commingling, restraint, and novel exposure, and 2- physical stress as hunger, injury, disease and environmental pressure (Breazile, 1996). Stress can be defined as any challenge that disrupts the animal's internal environment (Grandin, 1997). Stress is an important factor in the animal industry, because it has been observed its direct effect on growth, reproduction, meat quality and disease susceptibility (Herzog, 2007). Weaning and transportation are regarded as the top stressors that calves may experience (Qui et al., 2007). There is no available literature on the effects of weaning alone on calves.

The acute phase response is considered an exclusive biomarker of inflammation and/or infection (Arthington et al., 2003). The elevation of acute phase proteins (APPs) by weaning stress has been reported (Wittum et al., 1996 and Arthington et al., 2005). Triggered by inflammatory signals (cytokines) which include interleukin (IL-1 \& IL-6), tumor necrosis factor- $\alpha$ and interferon- $\gamma$. This inflammatory cytokines are the mediators of immunological and pathological responses to stress and infection (Tizard, 2004).
Accordingly, the concentration of acute phase proteins might be a useful indicator of stress response in calves. The objective of this study was to determine the effect of weaning as a stressor on some acute-phase proteins (Haptoglobin, Fibrinogen and ceruloplasmin) response in newly weaned buffaloe calves.

\section{MATERIALS and METHODS}

\section{(A) Animals:}

The study was carried out on 10 buffaloe calves of both sex ( 6 males and 4 females) of the same age ( 2 months) and body weight $(65-70 \mathrm{~kg})$ and belonging to a private farm at Sharkia Governorate. The calve were clinically healthy, without any signs of scour or respiratory tract infections. They were examined for internal and external parasites and undergo sharp weaning (complete milk restriction) at the same time. They were fed on ration consisted of wheat bran and broken corn and beans.

\section{(B) Samples and adopted methods: \\ (1) Blood samples:}

Before weaning two blood samples were collected from each animal, through jugular vein puncture, first one was collected on heparin as an anticoagulant for 
determination of fibrinogen, ceruloplasmin and cortisol levels. The second blood sample was collected without anticoagulant to obtain clear, nonhaemolysed sera for measuring the levels of haptoglobin, albumin and total serum protein. On the third and fifth day postweaning, two blood samples were collected by the same way. Plasma fibrinogen, ceruloplasmin, cortisol levels, serum haptoglobin, albumin and total protein levels were determined according to the methods reported by kits of biosystems S.A (Spain) and Bio-Med diagnostics (Egypt).

\section{(2) Faecal samples:}

Faecal samples collected from all animals under test to be examined microscopically using direct smear, flotation and sedimentation techniques (Coles, 1986).

(C) Statistical analysis:

Data were performed according to Snedecor and Cochran (1984).

\section{RESULTS}

Table 1: Leukocytes counts of the calves $(n=10)$ pre- and post-weaning

\begin{tabular}{lccc}
\hline \multicolumn{1}{c}{ Item } & Before weaning & $\begin{array}{c}\mathbf{3} \text { days } \\
\text { post-weaning }\end{array}$ & $\begin{array}{c}\mathbf{5} \text { days } \\
\text { post-weaning }\end{array}$ \\
\hline WBCs (10 cells/L) $^{\prime}$ & $8.05 \pm 1.4$ & $8.45 \pm 1.31$ & $9.70 \pm 1.24$ \\
\hline Neutrophil (\%) & $36.34 \pm 2.32$ & $38.70 \pm 2.14$ & $41.22 \pm 2.29$ \\
\hline Lymphocyte (\%) & $57.44 \pm 1.81$ & $54.24 \pm 1.64$ & $52.13 \pm 1.76^{*}$ \\
\hline Neutrophil/lymphocyte & $0.63 \pm 0.01$ & $0.71 \pm 0.02$ & $0.79 \pm 0.03^{* * *}$ \\
\hline
\end{tabular}

$*$ = Significant at 0.05

*** Significant at 0.001

Table 2: The mean concentrations of plasma fibrinogen, ceruloplasmin, cortisol and serum haptoglobin in calves $(\mathrm{n}=10)$ pre- and post-weaning

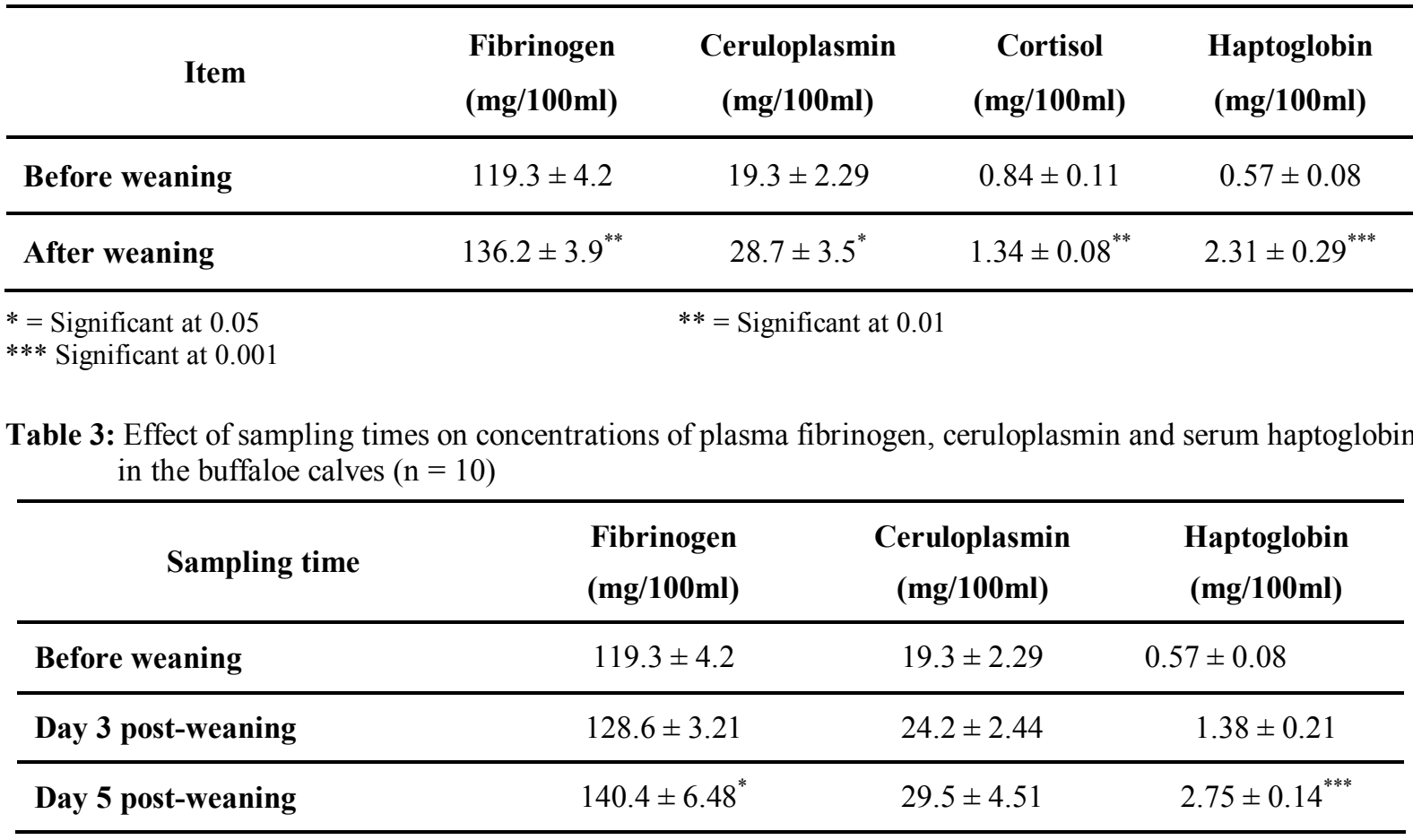

$*=$ Significant at 0.05

*** Significant at 0.001 
Table 4: Effect of sex of calf on mean concentrations of plasma fibrinogen and ceruloplasmin and serum haptoglobin in the buffaloe calves

\begin{tabular}{|c|c|c|c|c|c|c|}
\hline \multirow{2}{*}{ Item } & \multicolumn{2}{|c|}{$\begin{array}{l}\text { Fibrinogen } \\
(\mathrm{mg} / 100 \mathrm{ml})\end{array}$} & \multicolumn{2}{|c|}{$\begin{array}{c}\text { Ceruloplasmin } \\
(\mathrm{mg} / \mathbf{1 0 0 m l})\end{array}$} & \multicolumn{2}{|c|}{$\begin{array}{l}\text { Haptoglobin } \\
(\mathrm{mg} / \mathbf{1 0 0 m l})\end{array}$} \\
\hline & $\begin{array}{l}\text { Heifer } \\
(n=4)\end{array}$ & $\begin{array}{l}\text { Steer } \\
(\mathrm{n}=6)\end{array}$ & $\begin{array}{l}\text { Heifer } \\
(n=4)\end{array}$ & $\begin{array}{l}\text { Steer } \\
(\mathrm{n}=6)\end{array}$ & $\begin{array}{l}\text { Heifer } \\
(n=4)\end{array}$ & $\begin{array}{l}\text { Steer } \\
(\mathrm{n}=6)\end{array}$ \\
\hline Before weaning & $\begin{array}{c}118.4 \pm \\
4.71\end{array}$ & $\begin{array}{c}119.15 \pm \\
3.81\end{array}$ & $21.7 \pm 2.41$ & $16.4 \pm 1.1$ & $0.95 \pm 0.24$ & $0.88 \pm 0.16$ \\
\hline After weaning & $\begin{array}{c}133.3 \pm \\
5.41\end{array}$ & $\begin{array}{c}132.2 \pm \\
4.91\end{array}$ & $\begin{array}{l}31.0 \pm \\
2.12^{* * *}\end{array}$ & $\begin{array}{l}26.0 \pm \\
1.91^{* *}\end{array}$ & $1.91 \pm 0.43$ & $1.96 \pm 0.65$ \\
\hline
\end{tabular}

$* *$ Significant at 0.01

*** Significant at 0.001

Table 5: The mean concentrations of serum total protein and albumin in calves $(\mathrm{n}=10)$ pre- and post-weaning

\begin{tabular}{lcc}
\hline Item & $\begin{array}{c}\text { Total protein } \\
(\mathbf{g m} / \mathbf{d L})\end{array}$ & $\begin{array}{c}\text { Albumin } \\
(\mathbf{g m} / \mathbf{d L})\end{array}$ \\
\hline Before weaning & $7.64 \pm 2.37$ & $3.21 \pm 0.22$ \\
\hline After weaning & $6.49 \pm 1.14$ & $2.81 \pm 0.14$ \\
\hline
\end{tabular}

\section{DISCUSSION}

Weaning stress is composed of the psychological stress of breaking maternal and social bonding and the physical stress of nutritional change. Accordingly, weaning stress is recognized as a main cause of many health problems in cattle with important economic implications (Khan et al., 2007).

Natural weaning occurs as milk supply declines and as consumption of solid food by the calf increased. Results of this study were reported in tables 1, 2, 3, 4 and 5. The parasitological examinations of faecal samples revealed that all examined calves were free from internal and external parasites. This ensure that the physiological stress responses were not due to causes other than weaning.

The result of leukocyte count of calves pre and post weaning were recorded in table (1). The white blood cells count were within normal ranges for all calves, but the neutrophil: lymphocyte ratios were higher on third and fifth day of weaning, respectively than before weaning. This mainly due to a significantly reduction in the percentage of lymphocyte with an elevation of neutrophil percentage. Previous studies have investigated changes in leukocytes as potential biomarkers of physiological stress. Isolation of calves from their dams increases the neutrophil: lymphocyte ratio (Phillips et al., 1991). Moreover, Hickey et al. (2003) reported that the increased plasma cortisol level following a stressful event as weaning can reduce neutrophil adhesion to blood vessel epithelial cells, thereby increasing blood neutrophil concentration and neutrophil: lymphocyte ratios.

So, our findings confirmed that a weaning challenge affects leukocytes levels, and the neutrophil: lymphocyte ratio may be an effective biomarker of stress response.

Acute phase proteins is a group of hepatic glycoproteins produced following direct stimulation from proinflammatory cytokines which have proteolysis effect, so, the amino acids liberated from the body tissues are likely being incorporated into acute-phase proteins (APP) by the liver (Makimura and Suzuki, 1982). Circulating concentrations of APP is a useful tool for the health status because their concentration increase in cattle in response to stress stimuli (Baumann and Gauldie, 1994).

The results of biochemical analysis of serum and plasma of examined calves, are recorded in tables $(2$ and 5). They reveals that the levels of APP ( $\mathrm{Hp}, \mathrm{Fb}$, CRP) are very low in buffaloe calves before weaning. These results are similar with those previously reported by Marimatsu et al. (1992) who mentioned that normal cattle have Hp concentration less than $0.1 \mathrm{~g} /$ litre. Threshold value above $0.4 \mathrm{~g} /$ litre is an indicator of infection or stress. Hp is a hemoglobin binding protein and is considered the main APP in 
cattle, its normal physiological values is $10 \mu / \mathrm{ml}$. Recently, Gronlund et al. (2005) reported that Hp is present in normal bovine sera at a level of $100 \mu / \mathrm{ml}$ or less, and its level increases as much as 10 fold in response to infection or stress, and its concentration below the detection limit was considered as good indicator for health; on the other hand, Alsemgeest et al. (1995) reported that Hp concentration in healthy, unstressed cattle are often undetectable.

The results of examined calves after weaning show an elevation in all APP (Table 2), comparing with values obtained before weaning. This significant increases was a direct result of the stress associated with the weaning process. Similar increases in APP concentrations were observed in studies of Arthington et al. (2005). Moreover, Arthington et al. (2003) recorded the same results after measuring acute phase proteins in freshly weaned beef calves over two consecutive years and each of the APP increased overtime following weaning.

This quick response in APP concentration following weaning is due to the separation of calves from their dams. Increase in Hp concentration was much higher than fibrinogen and ceruloplasmin concentrations. This difference is due to the unique character of $\mathrm{Hp}$ unlike fibrinogen and ceruloplasmin, which exist at basal levels in unstressed cattle; Hp concentration are virtually undetectable in the blood of non stressed calves (Makimura and Suzuki., 1982). There is no doubt that there is non specific elevation in concentration of acute phase proteins in the blood of calve associated with weaning stress (Tizard, 2004 and Arthington et al., 2005).

Concerning plasma cortisol concentration, table (2) showed a higher values after weaning comparing with values obtained before weaning (Crookshank et al., 1979). Cortisol is highly immunosuppressive agent, released from the animal's adrenal gland whenever they undergo stress (Hickey et al., 2003).

Concerning serum albumin and total proteins levels in this study, there was non significant decrease in their levels (Table 5). Similar findings were observed by Eckersall and Conner (1988) who reported that the acute phase response leads to increased serum level of a number of positive acute phase proteins and to a concomitant decrease in negative acute phase proteins such as albumin.

In this study, obtained results revealed that heifers had greater $(\mathrm{P}<0.001)$ serum ceruloplasmin concentration than steers (Table 4), but calf sex was not important for haptoglobin or fibrinogen concentrations. On other hand, there is no significant difference of ceruloplasmin concentration (Table 3) while APP concentration of postweaning were significantly higher than those reported before weaning.

Lastly, in this study, we found that weaning stress alters the neutrophill: lymphocytes ratio and stimulate the production of hepatic APPs, and increase cortisol level, in newly weaned buffaloe calves.

\section{CONCLUSION}

In this study, weaning produced variable responses on the APP reaction in calves. The quantification of APP concentration in calves provide important clues to inflammatory stress reactions due to weaning. Further studies may be needed to determine whether APPs might be valuable indicators of stress following the weaning process.

\section{REFERENCES}

Alsemgeest, S.P.M.; Lambooy, I.E. and Meerkerk, B. (1995): Influence of physical stress on the plasma concentration of serum amyloid-A and haptoglobin in calves. Vet. Q. 17: 9-12.

Arthington, J.D.; Eicher, S.D.; Kunkle, W.E. and Martine, F.G. (2003): Effect of transportation and commingling on the acute phase protein response, growth and feed intake of newly weaned beef calves. J. Anim. Sci. 81: 1120-1125.

Arthington, J.D.; Spears, J.W. and Millen, D.C. (2005): The effect of early weaning on feedlot performance and measures of stress in beef calves. J. Anim. Sci., 83: 933-939.

Baumann, H. and Gauldie (1994): The acute phase response. Immunol. Today. 15: 74-80.

Breazile, J.E. (1996): The physiology of stress and its relationship to mechanisms of disease and therapeutics. Vet. Clin. N. Am., 4: 441-480.

Coles, E.H. (1986): Veterinary Clinical Pathology. $4^{\text {th }}$ Ed. Saunders Co. Philadelphia, London, Toronto.

Crookshank, H.R.; Elissalde, M.H. and Clanton, D.C. (1979): Effect of transportation and handling of calves upon blood serum composition. J. Anim. Sci., 48: 430-435.

Eckersall, P.D. and Conner, J.G. (1988): Bovine and canine acute phase proteins. Vet. Res. Commun., 12: 169- 178.

Grandin, T. (1997): Assessment of stress during handling and transport. J. Anim. Sci., 75: 249257.

Gronlund, V.C.; Hallen Sandgren and K. Person Waller (2005): Haptoglobin and serum amyloid A in milk from dairy cows with chronic subclinical mastitis. Vet. Res. 36 (2): 191-198.

Herzog, K.R. (2007): The effect of weaning stress on the serum protein profile of calves: a 
proteomic analysis. Master Thesis, University of Saskatchewan, Saskatoon.

Hickey, M.C.; Drennan, M. and Earley, B. (2003): The effect of abrupt weaning of suckler calves on the plasma concentrations of cortisol, catecholamines, leukocytes, acute-phase proteins and in vitro interferon-gamma production. J. Anim. Sci. 81: 2847-2855.

Khan, A.M.; Lee, H.J.; Lee, W.S.; Kim, H.S. and Choi, Y.J. (2007): Pre - and postweaning performance of Holstein female calves fed milk through step-down and conventional methods. J. Dairy Sci., 90: 876-885.

Makimura, S. and Suzuki, N. (1982): Quantitative determination of bovine serum haptoglobin and its elevation in some inflammatory disease. Jpn. J. Vet. Sci., 44: 15-21.

Marimatsu, M.; Sarikaputi, M. and Saito, M. (1992): Bovine haptoglobin: single radial immunodiffusion assay of its polymeric forms and dramatic rise in acute phase sera. Vet. Immun., 33: 365-372.
Phillips, W.A.; Jmiewcz, P.E. and Von Tungeln, D.L. (1991): Effect of pre- and postweaning management system on the performance of Brahman crossbred feeder calves. J. Anim. Sci., 69: 3102-3111.

Qui, X.; Arthington, J.D.; Riley D.G.; Chase, C.C.; Philips, W.A.; Coleman, S.W. and Olson, T.A. (2007): Genetic effects on acute phase protein response to the stresses of weaning and transportation in beef calves. J. Anim. Sci., 85: 2367-2374.

Snedecor, G.W. and Cochran, W.G. (1984): Statistical Methods ( $6^{\text {th }}$ Ed.) Iowa State Univ. Press. USA.

Tizard, I.R. (2004): Veterinary Immumology: $7^{\text {th }}$ ed. Saunders, Philadelphia.

Wittum, T.E.; Young, C.R.; Stanker, L.H. and Littledike, E.T. (1996): Haptoglobin response to clinical respiratory tract disease in feedlot cattle. Am. J. Vet. Res., 57: 646-649.

\section{تأثير الفطام كعامل إجهاد على مستوى بروتين الطور الحاد في الام في عجول الجاموس المفطوم حديثاً \\ فؤاد حامد السنجري ، السبا محد نور ، أمل إبراهيم الثوربجي ، خالد محد الهادي ، عزة جودة مصبلحي أيوب}

Email: n_king2013@yahoo.com

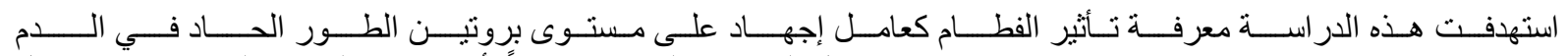

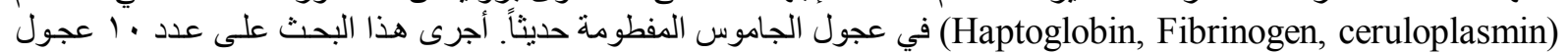

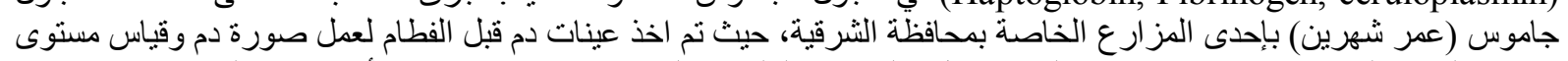

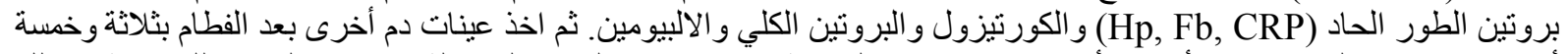

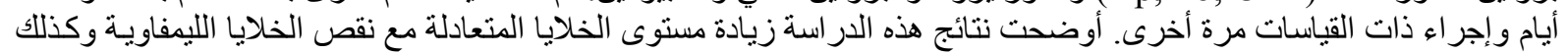

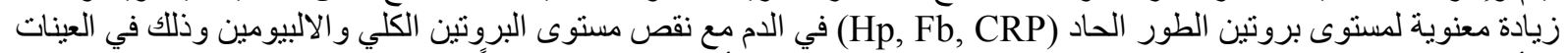

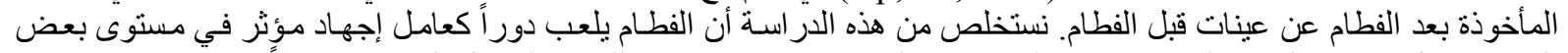
القياسات مثل بروتين الطور الحاد ـ مما يجعلها كمؤشر لحدوث هذا الإجهادـ وذللك في العجول المفطومة حديثاً. 